JPE (Jurnal Pendidikan Edutama) Vol. 7 No. 1 Januari 2020

P-ISSN : 2339-2258 (Print) E-ISSN: 2548-821X (Online)

http://ejurnal.ikippgribojonegoro.ac.id/index.php/JPE

\title{
PROFIL KEMANDIRIAN BELAJAR MAHASISWA DAN ANALISIS FAKTOR YANG MEMPENGARUHINYA: KOMUNIKASI ORANG TUA DAN KEPERCAYAAN DIRI
}

\author{
Nursaptini $^{1}$, Muhammad Syazali ${ }^{2}$, Muhammad Sobri ${ }^{3}$, Deni Sutisna ${ }^{4}$, Arif Widodo ${ }^{5}$ \\ ${ }^{1}$ Fakultas Keguruan dan Ilmu Pendidikan Universitas Mataram \\ email: nursaptini@unram.ac.id \\ ${ }^{2}$ Fakultas Keguruan dan Ilmu Pendidikan, Universitas Mataram \\ email: m.syazali@unram.ac.id \\ ${ }^{3}$ Fakultas Keguruan dan Ilmu Pendidikan Universitas Mataram \\ Email: muhammad.sobri@unram.ac.id \\ ${ }^{4}$ Fakultas Keguruan dan Ilmu Pendidikan Universitas Mataram \\ Email: denisutisna@unram.ac.id \\ ${ }^{4}$ Fakultas Keguruan dan Ilmu Pendidikan Universitas Mataram \\ Email: arifwidodo@unram.ac.id
}

\begin{abstract}
The purpose of this study is to analyze (1) the profile of learning independence, and (2) the effect of parental communication and confidence in student learning independence. This study uses quantitative expost-facto. The study was conducted on students of Elementary School Teacher Education (PGSD), FKIP Universitas Mataram. The sample consisted of 66 students from 2 different classes and determined by purposive sampling. Data collection uses a closed questionnaire. Analysis of learning independence profiles using descriptive statistics, namely percentages. The influence of parental communication and self-confidence were analyzed using correlation and regression. The results showed that students' learning independence can be grouped into 5 categories: very good $(68.18 \%)$, better $(27.27 \%)$, good $(1.51 \%)$, more than adequate $(1.51 \%)$, and less $(1.51 \%)$. The results of the correlation analysis of linear regression showed that the effect of self-confidence was higher $(R=0.553)$ compared to the effect of parental communication on student self-reliant learning $(R=0.451)$. This means that selfconfidence gives an effect of $55.30 \%$, and parental communication of $45.10 \%$ on the formation of student learning independence.
\end{abstract}

Keywords: Parental Communication, Self Confidence and Learning Independence

\begin{abstract}
Abstrak: Tujuan dari penelitian ini adalah menganalisis (1) profil kemandirian belajar, dan (2) pengaruh komunikasi orang tua dan kepercayaan diri terhadap kemandirian belajar mahasiswa. Penelitian ini menggunakan kuantitatif expost-facto. Penelitian dilakukan pada mahasiswa program studi Pendidikan Guru Sekolah Dasar (PGSD), FKIP Universitas Mataram. Sampel berjumlah 66 mahasiswa dari 2 kelas berbeda dan ditentukan secara purposive sampling. Pengumpulan data menggunakan angket tertutup. Analisis profil kemandirian belajar menggunakan statistik deskriptif yaitu persentase. Pengaruh komunikasi orang tua dan kepercayaan diri dianalisis menggunakan korelasi dan regresi. Hasil penelitian menunjukkan bahwa kemandirian belajar mahasiswa dapat dikelompokkan menjadi 5 kategori yaitu sangat baik (68.18\%), lebih baik (27.27\%), baik (1.51\%), lebih dari cukup (1.51\%), dan kurang (1.51\%). Hasil analisis korelasi dari regresi linear menunjukkan bahwa pengaruh kepercayaan diri lebih tinggi $(R=0.553)$ dibandingkan dengan pengaruh komunikasi orang tua terhadap kamandirian belajar mahasiswa $(R=0.451)$. Artinya bahwa kepercayaan diri memberikan pengaruh sebesar $55.30 \%$, dan komunikasi orang tua sebesar $45.10 \%$ terhadap pembentukan kemandirian belajar mahasiswa.
\end{abstract}

Kata kunci: Komunikasi Orangtua, Kepercayaan diri dan Kemandirian Belajar 


\section{PENDAHULUAN}

Pendidikan sering dimaknai sebagai transmisi nilai atau budaya dari pendidik kepada siswa atau dari orangtua kepada anak. Proses transmisi ini terjadi melalui komunikasi antara guru dan siswa atau antara orangtua dan anak. Komunikasi yang terjadi dalam rangka transmisi nilai inilah yang sesungguhnya merupakan bentuk komunikasi edukatif (Azzet, 2013: 41). Dalam kehidupan masyarakat seharihari, hubungan antarpribadi memainkan peran penting dalam membentuk kehidupan masyarakat, terutama ketika hubungan antarpribadi itu mampu memberikan dorongan kepada orang tertentu yang berhubungan dengan perasaan, pemahaman informasi, dukungan dan berbagai bentuk komunikasi yang mempengaruhi citra diri orang serta membantu orang untuk memahami harapan-harapan orang lain (Bungin, 2008: 262).

Kualitas hubungan dan komunikasi yang diberikan orangtua pada anak akan menentukan kualitas kepribadian dan moral mereka. Proses komunikasi antara orangtua dan anak dalam menanamkan perilaku positif berlangsung secara tatap muka dan berjalan dua arah artinya ketika orangtua mengkomunikasikan pesanpesan yang berisi nilai-nilai positif yang akan mempengaruhi perilaku anak ke arah yang positif pula, komunikasi berjalan dengan adanya interaksi di antara orangtua dan anak (Ramadhani, 2013:114).

Komunikasi merupakan suatu transaksi, proses simbolik yang menghendaki orang-orang mengatur lingkungannya dengan 1) membangun hubungan antarsesama manusia 2) melalui pertukaran informasi 3) untuk menguatkan sikap dan tingkah laku orang lain serta 4) berusaha mengubah sikap dan tingkah laku (Cangara, 2011: 19). Komunikasi orangtua dengan anak memegang peranan penting dalam membina hubungan keduanya. Komunikasi dalam keluarga tidak selamanya berjalan sesuai dengan yang diharapkan. Karena adanya hambatan dalam terjalinnya komunikasi intensif dalam keluarga (Naim, 2011: 212-214).

Komunikasi dalam keluarga memiliki dua fungsi yaitu fungsi sosial dan fungsi kultural. Fungsi sosial mengisyaratkan bahwa komunikasi itu penting untuk membangun konsep diri, aktualisasi diri, untuk memperoleh kebahagiaan, untuk menghindarkan dari tekanan dan ketegangan. Sedangkan fungsi komunikasi kultural, mempunyai hubungan timbal balik. Artinya peranan komunikasi disini adalah turut menentukan, memelihara, mengembangkan atau mewariskan budaya (Gunawan, 2013:219).

Orang tua yang kurang bisa berkomunikasi dengan anak akan menimbulkan kerenggangan atau konflik hubungan, sebaliknya orangtua yang dapat menerima anaknya sebagaimana adanya akan menyebabkan anak cenderung dapat tumbuh, berkembang, membuat perubahan yang membangun, belajar memecahkan masalah-masalah, dan secara psikologis semakin produktif, kreatif dan mampu mengaktualisasikan potensi sepenuhnya. Dalam menanamkan perilaku positif ada faktor yang mendukung seperti intensitas komunikasi yang tergolong sering dilakukan. Hal ini berdasarkan hasil 
penelitian Ramadhani (2013:119) bahwa komunikasi yang senantiasa dilakukan orangtua baik itu verbal dan nonverbal dapat membuat anak untuk berperilaku positif terutama perilaku mandiri, dan keterbukaan.

Perilaku mandiri sangat penting dalam proses belajar mahasiswa, dengan kemandirian belajar, siswa mampu menganalisis permasalahan yang kompleks, mampu bekerja secara individual maupun bekerja sama dengan kelompok dan berani mengemukakan gagasan. Kemandirian belajar yang dimiliki mahasiswa berpengaruh terhadap pemahaman materi pembelajaran (Syahputra, 2017: 369385).

Kemandirian belajar merupakan salah satu aspek yang dapat mempengaruhi kualitas pembelajaran. Karena kemandirian belajar membuat siswa dapat mengerjakan segala sesuatu sesuai dengan kemampuan yang dimilikinya secara optimal dan tidak menggantungkan diri kepada orang lain. Siswa yang memiliki kemandirian belajar yang tinggi akan berusaha menyelesaikan segala latihan atau tugas yang diberikan oleh guru dengan kemampuan yang dimilikinya sendiri. Sehingga secara tidak langsung akan mempengaruhi kualitas pembelajaran (Silvia Yanti \& Edy Surya, 2017:10)

Selain yang sudah dipaparkan di atas, kemandirian belajar seorang mahasiswa dapat dipengaruhi oleh faktor dalam dirinya yaitu kepercayaan diri. Dengan rasa percaya diri yang dimiliki, mahasiswa akan sangat mudah berinteraksi di dalam lingkungan belajarnya. Rasa percaya diri adalah sikap percaya dan yakin akan kemampuan yang dimiliki, yang dapat membantu seseorang untuk memandang dirinya dengan positif dan realistis sehingga ia mampu bersosialisasi secara baik dengan orang lain. Kepercayaan diri suatu bagian dari kehidupan yang unik dan berharga karena dengan kepercayaan diri seseorang akan lebih berani dalam menyampaikan pendapat didepan orang banyak dan lebih percaya dengan kemampuan yang dimilikinya (Indriawati, 2018:2).

Kepercayaan diri sangat perlu ditumbuhkan dalam diri mahasiswa, seseorang yang memiliki kepercayaan diri akan lebih yakin untuk melakukan sesuatu melalui sikap yang tenang dan seimbang dalam situasi sosial (Simorangkir, Menanti \& Aziz, 2014:69). Semakin tinggi tingkat rasa percaya diri yang dialami, maka semakin tinggi pula motivasi berprestasi siswa dan sebaliknyan (Asiyah, Walid, Kusumah, 223:2019). Selain itu, berdasarkan hasil penelitian Pratiwi \& Laksmiwati (2016:43) bahwa semakin tinggi kepercayaan diri yang dimiliki, maka semakin tinggi kemandirian belajarnya dan sebaliknya. Menurut Rahmayani (2019:88) bahwa mandiri dalam belajar itu sendiri merupakan suatu hal yang sangat penting dalam proses pembelajaran dikarenakan mandiri dalam belajar berpengaruh terhadap hasil prestasi belajar. Berdasarkan hasil penelitian Fauzi (2018:1) belajar mandiri adalah kemampuan yang sangat penting dalam proses belajar.

Kemandirian meliputi perilaku mengatur diri sendiri dan tidak bergantung pada orang lain dalam menyelesaikan semua tugas dalam kehidupannya, termasuk dalam belajar (Sobri dan Moerdiyanto, 2014: 53). 
Menurut Siswoyo (2013: 294) faktorfaktor yang mempengaruhi kemandirian, antara lain : 1) pola asuh orang tua, orang tua berperan dalam mengasuh membimbing, dan membantu mengarahkan anak menjadi mandiri. Keluarga merupakan pilar utama dan pertama dalam membentuk anak menjadi pribadi yang mandiri. 2) umur, semakin bertambah umur seseorang, perilaku mandiri akan terus berkembang dan perilaku tergantung akan berkurang. 3) Pendidikan, sekolah berperan memberikan kesempatan anak untuk bersikap mandiri melalui upaya mendidik, membimbing, dan melatih.

Perbedaan tingkat rasa percaya diri yang dimiliki mahasiswa tentu akan mempengaruhi tingkat kemandirian belajar dan mempengaruhi dalam kehidupan sehari-hari. Kurangnya kemandirian belajar mahasiswa dapat dilihat dari: 1) sulitnya mahasiswa maju kedepan kelas untuk menjawab soal ataupun menyampaikan ide/tanggapan yang berbeda dari teman yang lainnya. 2) Masih banyak terdapat siswa tidak betah dalam belajar, belajar hanya menjelang ujian. 3) mahasiswa belum memanfaatkan sarana dan sumber belajar dengan baik dan lain-lain.

Peranan komunikasi orangtua dan kepercayaan diri amatlah besar dalam membangun kemandirian belajar. Akan tetapi kenyataan yang terjadi dilapangan. Komunikasi dalam keluarga menjadi "barang mahal dan barang langka" karena masing-masing sibuk dengan urusan, pikiran dan perasaannya masing-masing. Oleh karena itu perlu dikaji lebih dalam tentang pengaruh komunikasi orangtua dan kepercayaan diri terhadap kemandirian belajar mahasiswa.

\section{METODE PENELITIAN}

Penelitian ini menggunakan pendekatan kuantitatif. Sedangkan jenis penelitian yang digunakan adalah penelitian expost-facto. Penelitian ini dilaksanakan pada mahasiswa semester 5 Program Studi Pendidikan Guru Sekolah Dasar Universitas Mataram. Adapun waktu penelitian dilaksanakan pada semester ganjil. Sampel berjumlah 66 mahasiswa dari 2 kelas berbeda dan ditentukan secara purposive sampling.

Teknik pengumpulan data dalam penelitian ini adalah dengan non tes yang menggunakan angket atau kuesioner, untuk mendapatkan data tentang komunikasi orang tua, kepercayaan diri siswa dan kemandirian belajr.

Angket yang digunakan dalam penelitian ini termasuk angket tertutup yang di mana opsi jawabannya sudah di sediakan dalam checklist. Sedangkan model skala yang digunakan dalam penelitian ini adalah skala likert. Dengan 4 alternatif jawaban yaitu: selalu, sering, jarang dan tidak pernah. Skor masing-masing 4,3,2 dan 1 untuk pernyataan yang bersifat positif dan skor 1,2,3 dan 4 untuk pernyataan negatif. Opsi jawaban ini untuk mengetahui komunikasi orangtua dan kepercayaan diri siswa. Sedangkan untuk angket kemandirian belajar menggunakan opsi jawaban: sangat setuju, setuju, tidak setuju, dan sangat tidak setuju. Skor masing-masing 4,3,2 dan 1 untuk pernyataan yang bersifat positif dan skor 1,2,3 dan 4 untuk pernyataan negatif.

Teknik Analisis Data yang digunakan yaitu analisis deskriptif dan inferensial. Analisis deskriptif digunakan untuk mendapatkan profil 
kemandirian belajar. Data dari angket dikonversi menjadi nilai rentang 10 100, dan diklasifikasikan berdasarkan 5 kategori. Adapun analisis inferensial yang digunakan adalah korelasi dan regresi. Pengaruh komunikasi orang tua $\left(\mathrm{X}_{1}\right)$, dan kepercayaan diri $\left(\mathrm{X}_{2}\right)$ terhadap kemandirian belajar mahasiswa (Y) mengacu pada Gambar 1 berikut ini.

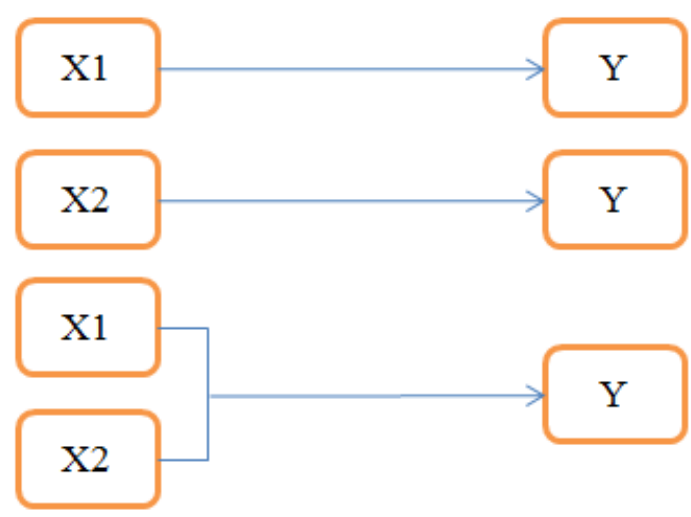

Gambar 1. Analisis Pengaruh $X_{1}$ dan $X_{2}$ terhadap $Y$

Korelasi dan regresi untuk pengaruh $\mathrm{X}_{1}$, dan $\mathrm{X}_{2}$ terhadap $\mathrm{Y}$ menggunakan analisis linear dan kuadratik. Pengaruh interaksi $\mathrm{X}_{1}$ dan $\mathrm{X}_{2}$ terhadap $\mathrm{Y}$ menggunakan korelasi dan regresi linear.

\section{HASIL DAN PEMBAHASAN}

\section{Profil Kemandirian Belajar}

Hasil analisis deskriptif menunjukkan bahwa $68.18 \%$ mahasiswa memiliki kemandirian belajar dengan kategori sangat baik (A), $27.27 \%$ lebih baik $(\mathrm{B}+)$, dan kategori baik (B), lebih dari cukup (C+) dan kurang sebesar (D) 1.51 (Gambar 1). Dominansi kategori sangat baik menyiratkan bahwa sistem perkuliahan yang diimplementasikan di program studi PGSD FKIP Universitas Mataram berdampak positif bagi mahasiswa. Faktor lain yang berperan adalah lingkungan keluarga dan masyarakat sekitar tempat tinggal.
Secara umum, kemandirian belajar mahasiswa dipengaruhi oleh 2 faktor. Faktor-faktor tersebut adalah faktor internal dan faktor eksternal. Profil kemandirian belajar yang terkespresi/teramati adalah resultan dari kedua faktor tersebut. Faktor internal adalah faktor yang bersifat genetis dan herediter. Genetis artinya ada gen (sifat genotip) yang berpotensi untuk terekspresi melalui transkripsi dan translasi. Hereditas, artinya dapat diturunkan dari parental ke filialnya.

Faktor eksternal, faktor dari lingkungan, mencakup semua elemen dari luar yang berinteraksi dengan diri mahasiswa. Elemen-elemen tersebut adalah keluarga, teman bermain, guru, dosen dan lain sebagainya. Faktor eksternal juga dapat mencakup fenomena sosial yaitu sikap dan perilaku. 


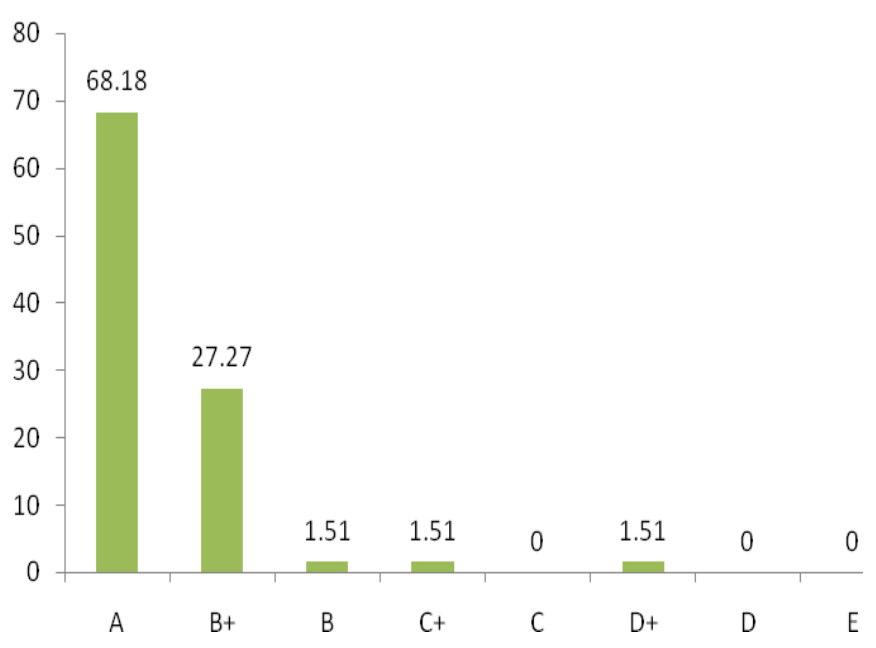

Gambar 1. Profil Kemandirian Belajar Mahasiswa

\section{Pengaruh Komunikasi Orang Tua dan Kepercayaan Diri}

Komunikasi orang tua adalah faktor eksternal, dan kepercayaan diri merupakan faktor internal. Analisis korelasi dari regresi linear menunjukkan bahwa pengaruh kepercayaan diri lebih tinggi $(\mathrm{R}=0.553)$ dibandingkan dengan pengaruh komunikasi orang tua terhadap kamndirian belajar mahasiswa $(\mathrm{R}=0.451)$. Artinya bahwa kepercayaan diri memberikan pengaruh sebesar $55.30 \%$, dan komunikasi orang tua sebesar $45.10 \%$ terhadap pembentukan kemandirian belajar mahasiswa.

Berdasarkan analisis korelasi dari regresi kuadratik, pengaruh kepercayaan diri dan komunikasi orang tua secara berturut-turut adalah $56.04 \%$ dan $55.32 \%$ terhadap kemandirian belajar mahasiswa. Terdapat selisih $0.74 \%$ pada pengaruh kepercayaan diri, dan $1.22 \%$ pada komunikasi orang tua.
Walaupun selisihnya terbilang kecil, namun hasil analisis tersebut menunjukkan bahwa prediktor regresi kuadratik lebih baik dibandingkan dengan regresi linear.

Secara matematik, persamaan regresi linear untuk pengaruh kepercayaan diri $\left(\mathrm{X}_{2}\right)$ terhadap kemandirian belajar $(\mathrm{Y})$ adalah $\mathrm{Y}=$ $0.578 \mathrm{X}_{2}+24.380$. Persamaan regresi kuadratiknya adalah $\mathrm{Y}=2.7\left(\mathrm{X}_{2}\right)^{2}-$ 44.430. Persamaan regresi linear untuk pengaruh komunikasi orang tua $\left(\mathrm{X}_{1}\right)$ terhadap kemandirian belajar (Y) adalah $\mathrm{Y}=0.316 \mathrm{X}_{1}+$ 44.227. Persamaan regresi kuadratiknya adalah $\mathrm{Y}=$ $0.988\left(\mathrm{X}_{1}\right)^{2}+25.178$. Grafik regresi linear dan kuadratik untuk pengaruh kedua variabel bebas terhadap variabel terikat dapat diamati pada Gambar 2.

Jika diinteraksikan, pengaruh komunikasi orang tua dan kepercayaan diri sekaligus berdasarkan hasil analsisi regresi linear adalah 


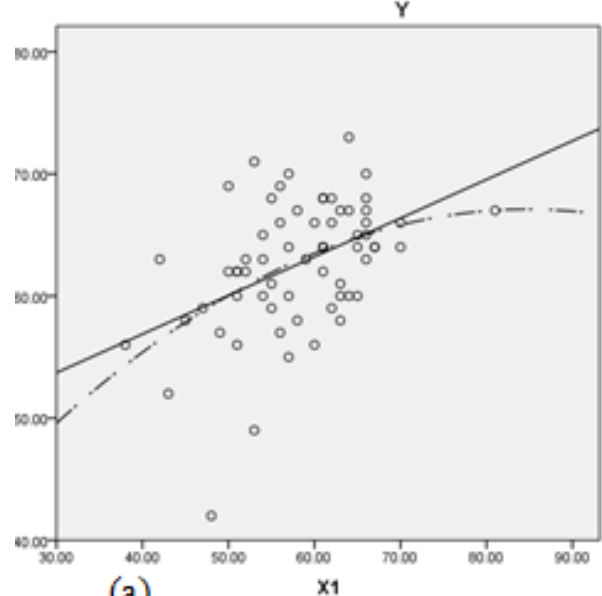

(a)

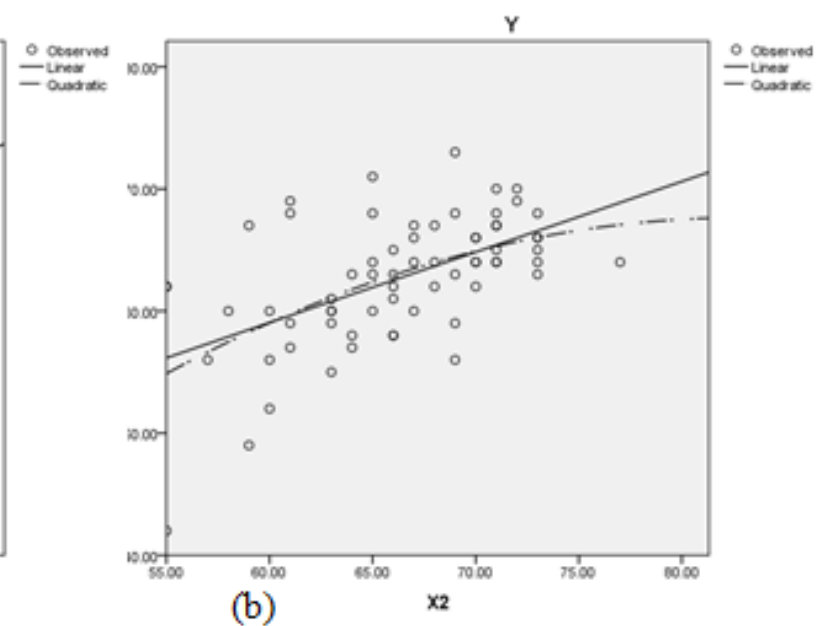

(b)

Gambar 2. Grafik Pengaruh Komunikasi Tua (a) dan Kepercayaan diri (b) terhadap Kemandirian Belajar Mahasiswa

Jika diinteraksikan antara komunikasi orang tua dan kepercayaan diri, kemudian dilihat pengaruhnya terhadap kemandirian belajar mahasiswa, korelasinya adalah 0.553 (55.30\%). Persamaan regresi linear bergandanya adalah $\mathrm{Y}=0.170 \mathrm{X}_{1}+$ $0.457 \mathrm{X}_{2}+22.521$.

Paparan hasil analisis di atas memberikan penjelasan bahwa kemandirian belajar mahasiswa Prodi PGSD Universitas Mataram sudah terbentuk dengan baik. Kemandirian belajar sangatlah penting bagi mahasiswa untuk menghadapi persoalan kehidupan yang lebih kompleks terlebih pada zaman dengan perubahan yang begitu cepat. Selain itu, kemandirian belajar yang sudah terbentuk dapat dijadikan sebagai modal untuk memaksimalkan dan meningkatkan hasil belajar. Penelitian Sobri dan Moerdiyanto (2014: 43) menegaskan bahwa kemandirian belajar dapat membengaruhi hasil belajar, dengan kata lain semakin baik kemandirian belajar maka baik pula hasil belajar.
Hasil analisis di atas juga menjelaskan bahwa komunikasi orang tua dan kepercayaan diri berpengaruh terhadap kemandirian belajar. Peran komunikasi orang tua sangat penting untuk dilibatkan dalam proses pendidikan.

Orang tua juga harus bisa berkomunikasi secara baik dengan guru/dosen, untuk berkolaborasi dalam menangani dan mengontrol kegiatan belajar anak atau peserta didik. Hasil Megawati dan Kahar (2017:34) menegaskan bahwa kolaborasi komunikasi orang tua dengan guru/ dosen dapat meningkatkan kualitas pembelajaran sehingga kemandirian belajar peserta didik dalam terbentuk dengan baik.

Perkembangan pendidikan dan masyarakat memberi dampak yang signifikan terhadap hasil proses pendidikan. Awal mula pendidikan di mulai dari keluarga sebelum masuk jalur pendidikan formal. Ketika anak didik telah masuk jalur pendidikan formal tidak berarti tanggung jawab pendidikan sepenuhnya berpindah ke tangan guru/pendidik (Akib, Guntur, \& 
Salam, 2016; Akib \& Salam, 2016; Amanda, Salam, \& Saggaf, 2017). Peranan orang tua juga sangat menentukan tingkat perkembangan anak dalam menempuh pendidikan.

Selain komunikasi orang tua, percaya diri juga turut menentukan tingkat kemandirian belajar. Menurut Fitri, Zola, Ifdil (2018:4) bahwa kepercayaan diri merupakan aspek yang berkontribusi membangun aspek optimis. Dijelaskan juga oleh Suhardita (2011:134) bahwa seseorang yang memiliki keyakinan diri yang tinggi, memiliki sikap penerimaan ketika mendapatkan penilaian dari teman dan memiliki sikap selalu berusaha lebih baik. Percaya diri termasuk salah satu aspek kepribadian yang sangat penting dalam kehidupan manusia. Orang yang percaya diri, yakin atas kemampuan mereka sendiri serta memiliki pengharapan yang realistis, bahkan ketika harapan mereka tidak terwujud, mereka tetap berpikiran positif dan dapat menerimanya (Kemdiknas.go.id, 2012).

Rasa percaya diri berkaitan dengan sikap mental yang membuat seseorang yakin pada dirinya bahwa ia mampu melakukan atau berbuat sesuatu. Orang yang percaya diri memiliki konsep diri positif, memiliki keyakinan yang kuat pada dirinya, dan memiliki pengetahuan akurat terhadap kemampuan yang dimilikinya.

\section{SIMPULAN}

Berdasarkan hasil analisis data maka dapat disimpulkan bahwa kemandirian belajar mahasiswa prodi PGSD universitas mataram sebesar 68.18\% memiliki kemandirian belajar dengan kategori sangat baik. Hasil analisis korelasi dari regresi linear menunjukkan bahwa pengaruh kepercayaan diri lebih tinggi $(\mathrm{R}=$ 0.553) dibandingkan dengan pengaruh komunikasi orang tua terhadap kamndirian belajar mahasiswa $(\mathrm{R}=$ 0.451). Artinya bahwa kepercayaan diri memberikan pengaruh sebesar $55.30 \%$, dan komunikasi orang tua sebesar $45.10 \%$ terhadap pembentukan kemandirian belajar mahasiswa. Adapun jika diinteraksikan pengaruh antara komunikasi orang tua dan kepercayaan diri secara bersamaan terhadap kemandirian belajar mahasiswa, korelasinya adalah 0.553 atau $55.30 \%$.

\section{DAFTAR RUJUKAN}

Akib, H., \& Salam, R. (2016). Analisis Kualitas Pelayanan Publik Berbasis Importance Performance Analysis (IPA) pada Kecamatan Kota Makassar. Jurnal Ilmiah Scientific Pinisi, 2(April 2016), 16-20.

Akib, H., Guntur, M., \& Salam, R. (2016). Civitas Academic Perception of "Blissful Services" for Recipient Postgraduate Program State University of Makassar, Indonesia. In International Conference on Public Organization VI (ICONPO VI) (pp. 340-350). Thammsat University, Tha Prachan Campus. Amanda, M. O., Salam, R., \& Saggaf, S. (2017). Pengaruh Supervisi Kepala Sekoalh terhadap Kinerja Guru di SMK Negeri 1 Bungoro Kabupaten Pangkep. In Prosiding Seminar Nasional Himpunan Sarjana Ilmu-ilmu Sosial (Vol. 2, pp. 149-154). 
Asiyah, Walid A, Kusumah R.G.T. (2019).Pengaruh Rasa Percaya Diri Terhadap Motivasi Berprestasi Siswa pada Mata Pelajaran IPA. Scholaria: Jurnal Pendidikan dan Kebudayaan. 9 (3). 217-226.

Azzet, A. M. (2013). Urgensi Pendidikan Karakter diIndonesia Revitalisasi Pendidikan Karakter Terhadap Keberhasilan Belajar dan Kemajuan Bangsa. Yogyakarta: Ar-Ruzz Media.

Bungin, B. (2008). Sosiologi Komunikasi Teori, Paradigma, dan Diskursus Teknologi Komunikasi di Masyarakat. Jakarta: Prenada Media Group.

Cangara, H. (2011). Pangantar Ilmu Komunikasi. Jakarta: PT Raja Grafindo Persada.

Fauzi, A \& Widjajanti DB. (2018). Selfregulated learning: the effect on student's mathematics achievement. IOP Conf.Series: Journal of Physic: Conf.Series 1097(2018) 012-139.

Fitri, E, Zola, N. Ifdil, I. (2018). Profil Kepercayaan Diri Remaja serta Faktor-faktor yang Mempengaruhi. JPPI (Jurnal Penelitian Pendidikan Indonesia). 4 (1): $1-5$

Gunawan, H. (2013). Jenis Pola Komunikasi Orangtua dengan Anak Perokok Aktif di Desa Jembayan Kecamatan Loa Kulu Kabupaten Kutai Kartanegara. Ejournal Ilmu Komunikasi. 1 (3): 218-233.

Indriawati, P. (2013). Pengaruh Kepercayaan Diri dan Kecerdasan Emosional terhadap Hasil Belajar Mahasiswa Universitas
Balikpapan. JPE (Jurnal Pendidikan Edutama ). 5 (2). 1-8

Kemdiknas.go.id. 2012. Membangun Rasa.

Megawati \& Fakhri Kahar. (2017). Pengaruh Komunikasi Orang Tua Dengan Guru terhadap Peningkatan Kualitas Pembelajaran. Jurnal Office, Vol.3, No.1, 34-42.

Naim, N. (2011). Dasar-dasar Komunikasi Pendidikan. Yogyakarta: Ar-Ruzz Media.

Pratiwi, I. D \& Laksmiwati, H. (2016). Kepercayaan Diri dan Kemandirian belajar pada Siswa SMA Negeri X. Jurnal Psikologi Teori dan Terapan. 7 (1): 43-49.

Ramadhani, R. (2013). Komunikasi Interpersonal Orangtua dan Anak dalam Membentuk Perilaku Positif Anak pada Murid SDIT Cordova Samarinda. Ejournal Ilmu Komunikasi. 1 (3): 112-121.

Simorangkir N.R, Menanti \& Azhar, A. (2014). Kontribusi Komunikasi Persuasif Guru terhadap Kepercayaan Diri dan Motivasi Belajar. Analitika Jurnal Magister Psikologi UMA. 6 (2) 68-76.

Siswoyo. (2013). Pendidikan Untuk Pencerahan \& Kemandirian Bangsa. Yogyakarta: Fakultas ilmu pendidikan Universitas Negeri Yogyakarta.

Sobri, M. dan Moerdiyanto (2014). Pengaruh Kedisiplinan dan Kemandirian Belajar terhadap Hasil Belajar Ekonomi Madrasah Aliyah di Kecamatan Praya. Harmoni Sosial Jurnal Pendidikan IPS. 1(1) 43-48.

Syahputra, D. (2017) Pengaruh Kemandirian Belajar dan 
Bimbingan Belajar terhadap Kemampuan dan Memahami Jurnal Penyesuaian pada Siswa SMA Melati Perbaungan. AtTawassuh, 2(2) 368-388.

Suhardita, Kadek. (2011). Efektivitas Penggunaan Teknik Permainan dalam Bimbingan Kelompok untuk Meningkatkan Percaya Diri Siswa (Penelitian Quasi
Eksperimen pada Sekolah Menengah Atas Laboratorium (Percontohan) UPI Bandung Tahun Ajaran 2010/2011). Jurnal UPI Edisi Khusus (1): 127-138.

Yanti, S \& Surya, E. (2017) Kemandirian Belajar dalam Memaksimalkan Kualitas Pembelajaran.https://www.researc hgate.net/publication/321833928. 